\title{
PART 2
}

\section{COASTAL SEDIMENT PROBLEMS}





\section{CHAPTER 17}

\section{SYSTEMATIC COLLECTION OF BEACH DATA}

Dennis W. Berg

Coastal Engineering Research Center

Washington, D. C

\section{ABSTRACT}

Theoretical considerations of beach behavior are often hampered by a lack of systematically obtalned data sets which reflect the beach environment. For specific studies, lack of time and money often prevent the collection of such data sets. Thus, any opportunity for the collection of such data, on a routine basis, should be fully explolted

In 1967, the U S Army Corps of Englneers and the State of California initiated a cooperatıve program to collect empirical data at selected locations along the Califomia coast. The objective was to establish a reservolr of repetitive, systematic observations, by qualified personnel, with the hope of securing a better understanding of the physical characteristics of the California shore and the littoral processes occurring there.

Once a sufficlent volume of data has been collected, analysis of the data wlll begin with the alm of determaning meaningful correlations between the various recorded parameters.

The number of distınct observations and sites dictated standardızed observational procedures and recording methods amenable to automatıc processing observational methods and a recording form were designed to provide a base of comparison and an efficlent means of processing the expected large volume of data Investigation of varıous methods of recording data led to the design of a sultable optical scanning form. This form, completed in the field by indıvidual observers, can automatically be converted to punched cards for further processing Experience in collecting similar data in connection with other studies of the Coastal Englneering Research Center influenced the selection of comparatıvely inexpensıve instruments for data collection.

Approximately 50 observation sites, extending from the Oregon-California boundary to the Unıted States-Mexican border are presently contributing data. These sites represent a wlde variety of shore types, beach sediments, geographlc orientations, and morphology It is anticipated that future expansion of this program will include sites other than those directly controlled by State agencies and will allow a more detalled description of the Californla shore Although not presently programmed, the extension of this study to other coastal areas of the United States where little or no information is presently avallable would be desirable, and could provide the necessary background for more comprehensive description of the overall behavior of the littoral zone

\section{INT'RODUCTION}

\section{BACKGROUND}

Although increasing emphasis is being placed on investigative study of the deep oceans, the boundary zones of the lands and seas remain generally unknown areas and of concern to relatively few investigators. In some respects, this classically forsaken zone should invite greater concern, for it is here that man leaves one environment

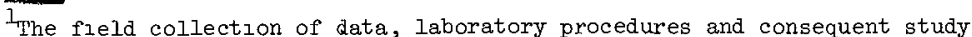
here reported are being carried out in connection with the general research program of the U S Army Corps of Englneers, Coastal Englneering Research Center However, the interpretations expressed are those of the author and are not necessarily concurred in by the Corps of Englneers. Permission granted by the Chief of Engineers to publish the information contained herein is appreciated 
to enter another This general lack of active interest can certalnly be partially attributed to the complex problems that confront those investigators intrepid enough to evince an interest, this boundary or littoral zone has all these forces and problems associated individually with land or sea occurring here in strange and unwonted interfusion.

However, despite this somewhat bleak prognosis, knowledge of the littoral zone and its many interacting forces has increased markedly in recent times, although a great deal is still to be learned Theoretical studies of shorelines, designed to increase our understanding of the environment are often hampered by a lack of systematıcally obtalned data sets which adequately reflect the dynamic character of the littoral zone. For specific, project-orlented studies, a lack of time and money generally prevents the collection of statistically significant data sets, this expediency often imposes misleading conclusions, resulting in projects that fall from the outset or are of only limited success. Thus, whenever an opportunity for the collection of environmental data on the littoral zone occurs, the occasion should be fully exploited and supported.

In late 1966, such an opportunity occurred when the State of California proposed the collection of empirical data at selected sites along the California Coast, utılızıng avallable state Park employees in order to document beach configurations. Due to the large volume of information that would ultimately be developed in a program of this type, the U. S. Army Corps of Englneers was asked to cooperatively participate in the study and act as custodian of all collected data with a possible overview toward complling the data so obtalned to eventually prepare a suitable summary report. The Coastal Engıneerıng Research Center (CERC), the primary representative of the Corps in this field, accepted the proposal, provided that the data would be obtanned and furnished in reasonably complete sets on a regular and systematic basis

The ultimate alm of the proposed data collection program was to establish a reservolr of repetitive, systematic observations which would be complled and made aval lable to the scientific community for applicable analytic study. The results of such studies would hopefully result in an increased understanding of the littoral environment and more particularly, greater knowledge of the physical characterlstics of the California shore and the littoral processes taking place.

\section{STUDY CONCEPT}

Early in 1967, after a series of meetings between representatives of all interested parties, the State of California began a test collection of field data at New Brighton State Beach located at the north end of Monterey Bay, primarily for the purpose of evaluating the extent of effort required by individuals to make a specified number of observations. Since the proposed study would utilize the employees of California as the observers, the collection of any data would necessarily be in addition to their regular duties, and could not unduly interfere with their normal routine. This initial test satisfactorly confirmed the feasibility of using such employees as observers. During the test, twice dally observations were made of surf characteristics, $1 . e$, wave helght and perıod, as well as direction of wave 
orlgin, tide level, and measurements of the location and elevation of the beach berm crest with respect to a reference point and an arbitrary datum Additionally, panoramic photographs of the beach were taken weekly.

At the outset of planning and coordınation of this study, It was readıly apparent that the intended scope of the study would yleld a large volume of data, of the order of 30,000 bits of information per month, which if improperly recorded and processed would negate the value of the data collected It was envisioned that approximately 70 observation sites would be included in the study in order to yleld data on a variety of shore conditions. The number of distinct observations and sites dictated standardized observational procedures for logical compatıbility of data and recording methods amenable to automatıc processing of the data Experience In collecting similar data in connection with other studies of the Coastal Englneering Research Center influenced the selection of the particular observations and a limited number of comparatıvely inexpensive instruments for making the observations. The experiences of the Center and of others in varıous methods of recording data was investıgated, and this led to the design of a specialized form employing optical scanning techniques to facilitate automatıc processing of data

Based on the results of the test at New Brlghton State Beach and of other simlar studies, the parameters selected for observation include

1 Surf observation (twıce da.ly)

a. Wave period

b. Wave helght

c. Wave direction

d. Type of breaking wave

2. Wind observatıons (twıce dally)

a. Velocity

b. Direction

3 Beach observations (once dally)

a. Beach berm crest elevation referred to some specific datum

b. Beach berm crest distance f'rom an established reference station

c. Foreshore slope angle

4 Littoral current observations (once dally)

a. Velocity

b. Direction

5 Tıde level (twıce dally)

6. Presence of $\mathrm{rlp}$ currents (twıce dally) 
7. Presence of beach cusps (twice dally)

8. Panoramic photographs of the observation site (monthly)

9. Collection of representative beach materials (monthly)

10. Water temperature (twice dally, this factor is observed only if It 25 obtalned for other purposes as a normal procedure at a particular site).

11. Reports of any unusual occurrences.

Addıtionally, perıodıc visıts by Corps of Englneers personnel to each observation site will be made to ensure that correct observational procedures are being consistently practiced and to emphasize and explain the importance to the study of doing so.

\section{PROCEDURES}

\section{SITE SELECTION}

As originally proposed by the State of California, observation sites would be established at selected beaches and shoreline parks, operated and staffed on a fulI year basis by the Department of Natural Resources, Division of Beaches and Parks. In the final selection of the observation sites, consideration beyond personnel avallability was given to the need for data to assist in the planning, design, construction or mantenance of coastal works in an area, correlation of the observed data with existing or planned basıc data collection programs, general shore conditions, 1.e., a varlety of shore exposures, orlentations and beach configurations, and spacing of sites to give the greatest coverage with the fewest locations Within those shoreline segments where there are no state operated beaches but where the collection of data $1 s$ desırable, locally operated beaches and parks have been included.

Of over 80 beaches operated under State direction, 39 observation sites have been established and are submiting data Additional sites will be added as the State expands its recreational program, and stations personnel at more beaches. Further, there are approximately 20 observation sites operated by local agencies which are being added to the study. A map of California with the locations of the active observation sites is shown in Figure 1. As previusly noted, the shoreline conditions vary at each site and typical illustrations of these conditions are shown in Figure 2. Conditions vary from pocket beaches to long, uninterrupted shores, and from heavily populated areas to remote, uninhabited shores.

\section{INSTRUCTIONS, RECORDING FORMS AND INSTRUMENTS}

To minımize varıance in data collection methods by the large number of Individuals involved, a set of instructions describing the preferred methods of observation was prepared and distributed to each site The instructions for each item, arranged in the same sequence as these items appear on the actual recording form, consist of short, 
concise statements relative to each individual parameter and the manner in which each observation is to be made. These instructions, lllustrated in Figure 3, have been laminated with plastic to facllitate their use in the field as a ready reference at the actual site In addition to these instructions, brief statements concerning individual observations have also been printed on the data recording form to facilitate the observational procedures.

The form on which the observations are recorded has been designed for automatic processing through an IBM 1231/1232, optical mark page reader, which converts the data to acceptable computer language $(4) *$. Once the value of an individual observation has been determined, the data is recorded on the form shown in Figure 4 by filling in the appropriate blanks with an ordınary lead pencıl.

Two comparatively inexpensive instruments have been selected for measurement of the three parameters, wind velocity, elevation of the beach berm crest and the angle of the foreshore slope. A Dwyer Wind Meter, shown in Figure 5, is used to measure the wind velocity rather than using visual estimates such as Beaufort Wind Scales. The instrument's simplicity of construction and use, as well as its comparative accuracy assures compatibility of data between observation sites An Abney Topographic Hand Level allows the measurement of the beach berm crest elevation in the normal manner, the angle of the foreshore slope is measured by using the level as an inclinometer. Use of the Abney Level in the latter fashion is show in Figure 6 .

Each slte has also been supplied with a measuring tape, a supply of plastic bags for collecting samples of the beach materials, a supply of fluorescein or rhodamine $B$ dye for use in observing the littoral current patterns, cameras, film and sturdy envelopes for mallng the data to the Coastal Englneering Research Center.

\section{METHODS OF OBSERVATION}

At each observation site, a permanent reference point with a known elevation has been established near the shoreline. Observations are referred to this station so that all subsequent data sets can be used to reflect variations of the littoral environment from a fixed reference. The observations are made during a normal inspection of the shoreline by personnel assigned to the area. These inspection tours usually occur twice a day so that two sets of observations are possible each day at each site. The various instruments, instructions and recording forms require no special handling and can easily be carried by the observer during his normal tour. Once on station, observation of the desired parameters by following the procedures outlined in the instructions and on the data-recording form is a simple task requiring approximately 20 minutes.

Observed data Is forwarded to the Coastal Engıneerıng Research Center on a weekly basıs, samples of the beach materials and photographs (obtalned monthly) are malled as taken

\section{OFFICE PROCEDURES}

At CERC, the data is processed through an optical mark page reader and converted

*Numbers in parentheses refer to References at end of report. 
to standard punched data cards which are stored for analysis in future studies The only data reduction now planned is the complation and data printout of the observations. However, once a statistically significant volume of data has been accumulated, detalled studies of data wlll be started to seek meaningful correlations between the varıous parameters.

Granulometrıc analysıs of beach materials is accomplished on a routine basıs by the Geology Branch of the Coastal Englneerıng Research Center as the samples are recelved. Utılizing a rapid sediment analyzer simllar to that described by Schlee(5), size distributionsl characteristics of the samples are calculated by computer technlques and include cumulative size-frequency distribution, median and mean diameters, standard deviation, skewness and kurtosis of each sample. Presently, this is the only analysis being made of the beach material samples, however, the samples are being retalned so that other types of analysıs (compositional, heavy mineral, etc.) can be made by investigators in the future if deemed desirable.

\section{EXAMPLES OF USE FOR COLLECTED DATA}

Although no detalled studies of the submitted data have yet been accomplished, several possible methods of investigation are discernible when scanning the observation forms and the results of beach material analysis and photographs. Examples of these methods of investigation are lliustrated, but are not intended as a complete catalogue of possible uses. Illustrative examples represent only minimum analysis. It is believed that the information wlll have many more uses beyond those suggested by the author

\section{SURF AND BEACH OBSERVATIONS}

Data from an observation site has been randomly selected to illustrate the possible correlations of the surf and beach observations. Approximately 60 days of record for Seacliff State Beach on Monterey Bay, collected durıng the sprıng of 1968, are shown In Figure 7 Although there are lapses of several days each in the record, apparently caused by lack of manpower at these times to collect the data, the record is essentially complete and 15 open to several qualitative interpretations.

For example, the data in Figure 7 shows for the recorded period that the waves were small, varying from 1 to 4 feet in helght, had rather long periods, averaglng slightly higher than 10 seconds and they orlginated from a distant generating area in the southwest quadrant. Generally, the waves broke on the shore as spllling waves. The overall response of the shore to these waves resulted in an accreting beach characterized by a lowering berm crest with a gentle foreshore slope.

Qualitatıvely, It can be stated that the predominant wave climate during this perıod was conducive to movement of avallable littoral materials toward the observation site and allowed it to remain in the area. Additional data will, in all probablity, record varyzng responses during other perıods of the year. Studies by Shepard $(6)$ and Trask $(7)$ have shown that Calıfornia beaches undergo annual cycles with general erosion of the beaches occurring during the winter months when large, steep waves accompanying storms out of the northwest predominate, and accretion during the summer months of southwesterly sea swells whlch return sand to the upper portion of the beach profıle. 
This type of data, once more of it has been accumulated and processed, will assist varıous indıviduals and agencies in project orlented studies of the Californıa shores. A case in point is a fecent report of the Corps of Engineers Los Angeles District on Newport Beach, California ${ }^{(8)}$, using data on beach sidths observed since 1954 by Mr. Robert E. Reed, Chief Lifeguard of that clty This information, in conjunction with studies of a more conventional nature was used to predict the time when the beach would erode to a dangerous position, and require restoration by placing sand fill on the shore. A summary of Reed's data as used by the Los Angeles D $\downarrow$ strict is shown in Figure 8 This dat is simllar to that being obtalned in the cooperative program reported on, as indicated in the instructions and observation form and Figure 7 .

Surf observations at locations on parts of the U. S. Coast other than those shown on Figure 1 are presently belng analyzed at CERC under a different study (2) (cooperation with USCG), but data collected under any of these studies will be correlated with any that may be avallable from any of the other study programs Observations of the surf are intended to supplement more detalled study of waves using recording wave gages installed at various locations on the coastline of the United States $(1)$

Complations of the observed data on surf characteristics and beach response should also prove useful in studies directed primarly toward the recreational aspects of the shore The ability to predict the overall characteristics of a beach for such uses as swimming and surfing wlll allow the appropriate agencles to assign varlous classifications for safety and use to the beaches.

\section{BEACH MATERIALS AMALYSIS}

As previously mentioned, analysis of sample beach materials recelved at CERC under this program is made by the Geology Branch The results of the analysis from the rapld sand analyzer are processed by computer methods ylelding the size-frequency distributions of the individual sanples as well as the computation of the statistical parameters which are descriptive of size distributions. Several typical examples of this process are shown in Table 1 . The samples listed were all obtained on 1 July of this year and are representative of the type of analyses presently being made

Avallability for comparison of the varıous parameters of the beach materials for many beach locations should result in additional understanding of the geomorphology of the Callforna shore, and when correlated with all the other observed data, should enhance the understanding of shore characteristics in relation to the materials composing the beach. An example of such a comparison is shown in Table 2 where mean diameters and standard deviations of the beach samples have been listed for a number of observation sites. The data listed in Table 2 is based on analyses of samples taken during the spring of 1968. The locations are listed in a north to south direction as shown on Flgure 1 and the variance in the physical characteristics of beach materials at different locatıons is indlcated.

As directed in the study instructions shown in Figure 3 , the samples of beach material are obtained from the wetted zone of the beach and although sampling is small compared to the whole beach area, hopefully the results of the sample analysis will bear some slgnificant relationship to the physical characteristics of the materials forming the entire beach. It is already clear that there is substantial variation in 
TABLE 1 - Typical Results of Computer Analysis of Beach Material Samples IIttoral Environment observations

\begin{tabular}{llll} 
PHI & MM. & Frequency & Cumulative \\
Slze & Size & Percent & Percent \\
\hline
\end{tabular}

Wright's Beach No 05021

$\begin{array}{rrrr}-1.00 & 2.000 & .00 & 00 \\ -.50 & 1.414 & 87.55 & 87.55 \\ .00 & 1.000 & 10.98 & 98.52 \\ .50 & .707 & 1.48 & 100.00 \\ 1.00 & .500 & .00 & 10000 \\ 1.50 & .354 & .00 & 100.00 \\ 2.00 & .250 & .00 & 10000 \\ 2.50 & .177 & .00 & 100.00 \\ 300 & 125 & .00 & 10000 \\ 350 & .088 & .00 & 100.00 \\ 4.00 & .062 & .00 & 100.00\end{array}$

San Simeon Beach No 05009

$\begin{array}{rrrr}.50 & .707 & .00 & .00 \\ 1.00 & .500 & 23.17 & 23.17 \\ 1.50 & .354 & 35.56 & 5873 \\ 2.00 & .250 & 29.18 & 8791 \\ 2.50 & .177 & 9.92 & 9784 \\ 3.00 & .125 & 2.16 & 100.00 \\ 3.50 & .088 & .00 & 10000 \\ 4.00 & .062 & 00 & 100.00\end{array}$

Carpinteria Beach No. 05014

$\begin{array}{rrrr}1.00 & .500 & .00 & 00 \\ 1.50 & .354 & 1125 & 11.25 \\ 2.00 & .250 & 29.71 & 40.96 \\ 2.50 & .177 & 37.91 & 78.88 \\ 3.00 & .125 & 19.67 & 98.55 \\ 3.50 & .088 & 1.45 & 100.00 \\ 4.00 & .062 & .00 & 100.00\end{array}$

Huntington Beach No. 05027

$\begin{array}{rrrr}.50 & .707 & .00 & .00 \\ 1.00 & .500 & 11.79 & 11.79 \\ 1.50 & 354 & 16.61 & 28.40 \\ 2.00 & .250 & 22.21 & 50.61 \\ 2.50 & .177 & 31.59 & 82.20 \\ 3.00 & .125 & 16.34 & 98.54 \\ 3.50 & .088 & 1.46 & 100.00 \\ 4.00 & .062 & .00 & 100.00\end{array}$

Sample taken 1 July 1968

STATISTICAL PARAMETERS

\begin{tabular}{lrrr} 
& PHI & & MM \\
\cline { 2 - 2 } Median & -64 & & 1.562 \\
Mean & -.63 & & 1.552 \\
Stand Dev & 18 & 1136 \\
Skewness & 138 & \\
Kurtosis & 6.85 &
\end{tabular}

Sample taken I July 1968

\begin{tabular}{lrrr}
\multicolumn{1}{l}{ STATISTICAI } & PARAMETERS \\
\cline { 2 - 2 } Median & PHI & MM \\
Mean & 1.40 & & 380 \\
Stand Dev. & 47 & & 372 \\
Skewness & 46 & & 383 \\
Kurtosis & 262 &
\end{tabular}

Sample taken I July 1968

\begin{tabular}{lrrr} 
& \multicolumn{2}{c}{ STATISTICAL PARAMETERS } \\
\cline { 2 - 2 } Median & 2.13 & & PHI \\
Mean & 229 \\
Stand. Dev & .41 & .232 \\
Skewness & .03 & & \\
Kurtosis & 2.13 &
\end{tabular}

Sample taken I July 1968

STATISTICAL PARAMETERS PHI M.

Median $\quad 1.99 \quad .252$

$\begin{array}{lr}\text { Mean } & 1.90 \\ \text { Stand. Dev. } .64 & 1.553\end{array}$

Skewness $\quad-.36$

Kurtosis 2.28 
TABLE 2 - Comparıson of Computer Derıved Statistıcal Parameters for Beach Material Samples - Liłtoral Environment Observations

\begin{tabular}{|c|c|c|c|c|c|}
\hline Location & $\begin{array}{l}\text { Date of } \\
\text { Sample }\end{array}$ & $\begin{array}{l}\text { Mean Dis } \\
\text { Undts }\end{array}$ & $\begin{array}{c}\text { meter } \\
\mathrm{mm}\end{array}$ & $\begin{array}{l}\text { Standard } \\
\phi \text { Units }\end{array}$ & $\begin{array}{c}\text { Deviation } \\
\mathrm{mm} .\end{array}$ \\
\hline Mackerricher & 1. Apr 68 & -0.05 & 104 & +030 & 0.82 \\
\hline Russian Gulch & 25 Apr 68 & +170 & 031 & +0.53 & 0.69 \\
\hline Van Damme & 8 Apr 68 & +010 & 093 & +102 & 049 \\
\hline Manchester & 11 May 68 & +0.80 & 0.57 & to 80 & 0.57 \\
\hline Goat Rock & 15 Apr 68 & +010 & 0.93 & +0.80 & 0.57 \\
\hline Wright's & $15 \mathrm{Apr} 68$ & +0.70 & 062 & to 87 & 055 \\
\hline Stinson & $17 \mathrm{Apr} 68$ & +2.15 & 023 & +0.39 & 076 \\
\hline Thornton & $15 \mathrm{Apr} 68$ & +185 & 028 & +0.39 & 0.76 \\
\hline Half Moon Bay & 15 Apr 68 & +0 50 & 0.71 & +0.45 & 0.73 \\
\hline Natural Bridges & 1. Apr 68 & +160 & 0.33 & +0.57 & 0.67 \\
\hline Twin Lakes & 8 Apr 68 & +1.25 & 042 & +0.48 & 072 \\
\hline New Brighton & $24 \operatorname{Mar} 68$ & +210 & 0.23 & +050 & 0.71 \\
\hline Seacliff & $6 \mathrm{Apr} 68$ & +200 & 025 & +o 48 & 0.72 \\
\hline Sunset & 5 Apr 68 & +190 & 0.27 & +0.42 & 0.75 \\
\hline Carmel River & 6 Feb 68 & +0.25 & 084 & +0 57 & 067 \\
\hline San Simeon & 9 Apr 68 & +1.40 & 0.38 & +o 45 & 0.73 \\
\hline Montana de Oro & 1. Nov 67 & +100 & 0.50 & +0.63 & 0.65 \\
\hline Plsmo & 1 Apr 68 & +2.40 & 019 & +0.30 & 0.81 \\
\hline El Capltan & 1 Apr 68 & +2.10 & 023 & to 36 & 0.78 \\
\hline Carpınterıa & 1 Feb 68 & +1.90 & 027 & +0.42 & 0.75 \\
\hline San Buenaventura & 1 Apr 68 & +2.10 & 0.23 & +o 42 & 075 \\
\hline McGrath & 1 Apr 68 & +0.70 & 062 & +0.33 & 080 \\
\hline Point Mugu & 1. May 68 & +200 & 0.25 & +0.36 & 0.78 \\
\hline Leo Carrillo & $3 \operatorname{Jan} 68$ & +1.35 & 039 & +0.50 & 071 \\
\hline Bolsa Chica & 6 Apr 68 & +075 & 0.59 & +0.60 & 066 \\
\hline Huntington & 1 May 68 & +1.75 & 030 & +0.50 & 0.71 \\
\hline Newport & 1. Apr 68 & +1.40 & 0.38 & +0.45 & 0.73 \\
\hline Doheny & 26 Apr 68 & +0.90 & 054 & +0.70 & 0.62 \\
\hline San Clemente & 19 Apr 68 & +145 & 037 & +0.50 & 0.71 \\
\hline Torrey Pines & $18 \mathrm{Apr} 68$ & +1.75 & 030 & +0.42 & 0.75 \\
\hline
\end{tabular}


TABLE 3 - Comparison of Varıations in Mean Diameters of Beach Materials Iittoral Environment Observations

\begin{tabular}{|c|c|c|c|c|c|c|c|c|}
\hline \multirow[b]{3}{*}{ Date } & \multicolumn{8}{|c|}{ Locations of Beaches } \\
\hline & \multicolumn{2}{|c|}{ Thornton } & \multicolumn{2}{|c|}{ San Simeon } & \multicolumn{2}{|c|}{ San Buenaventura } & \multicolumn{2}{|c|}{ Bolsa Chica } \\
\hline & $\phi$ Units & mm. & $\phi$ Units & $m m$. & 中 Unats & $\min$ & $\phi$ Unzts & $\mathrm{mm}$ \\
\hline 0 ct 67 & 160 & 033 & 2.05 & 0.48 & 215 & 022 & 220 & 022 \\
\hline Nov 66 & 200 & 025 & 125 & 0.42 & 210 & 023 & 130 & 0.41 \\
\hline Dec 67 & 205 & 0.24 & 145 & 0.37 & 200 & 025 & 095 & 052 \\
\hline $\operatorname{Jan} 68$ & 195 & 0.26 & 145 & 037 & 210 & 0.23 & 110 & 047 \\
\hline Feb 68 & 195 & 0.26 & 0.80 & 0.57 & 2.10 & 023 & 0.50 & 0.71 \\
\hline Mar 68 & 190 & 027 & 060 & 066 & 1.60 & 033 & 0.70 & 062 \\
\hline Apr 68 & 3.85 & 028 & 140 & 0.38 & 230 & 020 & 0.75 & 059 \\
\hline May 68 & 155 & 0.34 & 075 & 059 & 1.20 & 044 & 1.50 & 035 \\
\hline Jun 68 & & & 120 & 044 & 1.80 & 029 & 140 & o 38 \\
\hline
\end{tabular}


the composition of samples at different points in time from the same locations Table 3 lists the results of part of the beach material analyses for four observations sites for a 9-month period. It can be seen that the mean diameter of the materials varıes considerably, especially for the observation sites at San Simeon and Bolsa Chica State Beaches. This variation may be a result of resorting and redistributing by increased storm action that is typlcal along the California Coast during the winter months but it cannot be directly attributed to any one factor until sufficient data has been collected and interpreted.

\section{PHOTOGRAPHS OF OBSERVATION SITES}

Photography has long been an accepted method of documenting the condition of beaches and shoreline structures and in many cases has been the only evidence gathered. The use of such photography in a number of studies has revealed changes whlch would otherwise have been impossible to describe without having resorted to difficult, expensive and time-consuming surveying techniques. A historical record of the New Jersey shoreline by Vesper and Essick $(9)$ is an example of the Judicious use of photography, a capsule commentary on the variations of a large segment of the coastline of the United States is placed in one brief, easy-to-comprehend, volume. However, ground photographs by themselves do not allow quantitative descriptions of the shoreline variations which occur, and therefore can only complement data of a more conventional nature for this reason, panoramic photographs of each observation site are taken monthly. The photographs reveal the general conditions at each site which cannot be recorded on the observation form It is felt that the photographs will allow an investigator studying the data to form $1 \mathrm{~m}$ pressions of the observation sites which would not be otherwise possible unless he actually visited each site, and will hopefuliy assist in the interpretations of the data.

A serles of photographs, acquired under this study, are shown in Figures 9 and 10. Three overall views of El Capitan State Beach, plus three views to the south of the actual observation point at this beach are shown in Figure 9. Several recognizable landmarks are clearly discernible in all six photographs, such as the small grove of trees and the stone groin in the background, and these assist in the evaluation of the general beach condition. It can be seen that in November 1967 the beach was generally broad, whth a gentle foreshore slope, and had at least two berms, in January 1968 the beach was slightly narrower, having been recently affected by storm waves as indlcated by the cuspate tonal difference of the sand above the waterline in the left photograph and the beach scarp in the right photograph. An added inference is that wave conditions were conducive to the formation of beach cusps at the tame the photographs were taken By March 1968, the beach 1s still narrower and again shows recent effects of storms as denoted by seaweed and debris on the shore in the left photograph and the beach scarp, considerably larger than that shown in the photograph for January 1968, on the right.

Figure 10 is a series of six photographs taken at Natural Bridges State Beach over the period November 1967 through April 1968 The variation in the condition of the beach which is easily noted in these photographs reflects a seasonal cycle at this observation site. 
Detailed analysis of other observed data should be concurrently considered in order to confirm these conclusions but the photographs do allow rather quick analysis of overall beach condztions. All of the photographs taken at each observation site are being filed at the Coastal Englneering Research Center and will become a part of the data bank for future analytic studies.

\section{STUDY SUPPORT}

As stated, this study is a cooperative effort of the State of California and the U.S. Army Corps of Englneers. The State, acting through the Department of Hatural Resources Division of Beaches and Parks provides the necessary manpower for the colleciton of data. The cost of this manpower contribution at present far exceeds the other efforts in a monetary sense. A typical observation site can be initially equipped for under $\$ 100$ and requires sustaining funds of approximately $\$ 30$ per year. The funds for this support are budgeted under the general research program of the Coastal Engineering Research Center. It should be noted, however, that without the cooperation of the State of California, the collection of this type of data could not be unllaterally carried out by the Center.

The distant location of the Coastal Englneering Research Center from Callfornia makes assistance from other branches of the Corps of Englneers a requirement, the South Pacific Division and the Los Angeles and San Francisco District Engineer offices have been instrumental in the coordination and implementation of this study by providing the necessary technical lialson between the Center and local park employees at each observation site. Personnel of these offices, by their knowledge and experience, have contributed immeasurably in the selection of individual observation sites, in obtalning the excellent cooperation experienced to date from a large number of individual observers located at many distant points.

The initial complation and reduction of the collected data will be made by CERC as part of a much broader program of data collection and analysis, seekıng full understanding of littoral environment around the United States.

It is presently contemplated that this study wlll continue for three years, however, the value of the data could concelvably extend the life of the program well beyond this period. Specific analysis of the data will ultimately be made by scientists and engineers of the Center, but all data will be avallable to any interested investigator who desires to make use of 1 t.

\section{CLOSURE}

This study of the California shoreline is in no way unique or orlginal. The Netherlands $(3)$ has long led the world in documenting coastal varlations, and the Coastal Englneering Research Center 1 tself has conducted or supported similar studies of the shores of the United States, including those of California in more limited scope. However, it is felt that the frequency and number of observations, and the number of observation sites, place this study in a novel status. It is expected that future analysis of collected data will enhance understanding of the littoral environment and allow greater utilization of this zone by man. 


\section{ACKNOWLEDGEMENTS}

This study, entitled Littoral Environment observations, is being carried out in connection with the general research program of the U. S. Army Corps of

Engineers, Coastal Englneerıng Research Center in cooperation with the State of California, Department of Natural Resources. The success of the study will be primarly the result of the efforts of those many individuals who have shown an unbounded interest in observing the California shoreline and falthfully recording their observations for the future use of scientists and engineers Without these individuals, a study of this scope could not exist

NOTE Use of trade names or manufacturers in this report does not constitute an offlcial indorsement or approval of the use of such commercial hardware or software. 
]. Darling, J M., The Wave Record Program at CERC, U S Army Coastal Engineering Research Center Miscellaneous Paper 1-67 January 1967.

2. Darling, J M., Surf Observations Along the United States Coasts, Journal of Waterways and Harbors Division, Proceedlngs of the American Soclety of Civil Engineers, WWl, Feb 1968, pp 11-21.

3 Edelman, T.; Systematic Measurements Along the Dutch Coast, Proc., Coastal Englneering Conference, September 1966, Vol. I, Part 2, pp 483-501.

4. IBM Corp, IBM I231,1232 Optıcal Mark Page Readers, IBM Systems Reference Library, 1963, File No. 1231-03.

5. Schlee, J A., A Modifled Woods Hole Rapıd Sand Analyzer, Journal of Sedimentary Petrology, Vol. 36, No 2, June 1966, pp. $403-413$.

6 Shepard, F P ; Beach Cycles in Southern Callfornza, U S. Army Beach Erosion Board Technıcal Memorandum 20, July 1950

7. Trask, P D, Changes in Configuration of Polnt Reyes Beach, Cal1fornia, U. S Army Beach Erosion Board Technical Memorandum 91, September 1956

8, U, S. Army Corps of Engineers, Los Angeles District, Design Memorandum for Beach Stabilization, Stage 2, Construction in the Segment from Santa Ana River to Newport Pier, Orange County, Calıfornıa, August 1967, Plate 6

9 Vesper, W H and Essıck, M G., A Plctoral History of Selected Structures Along the New Jersey Coast, U. S Army Coastal Englneerıng Research Center Miscellaneous Paper 5-64, October 1964 


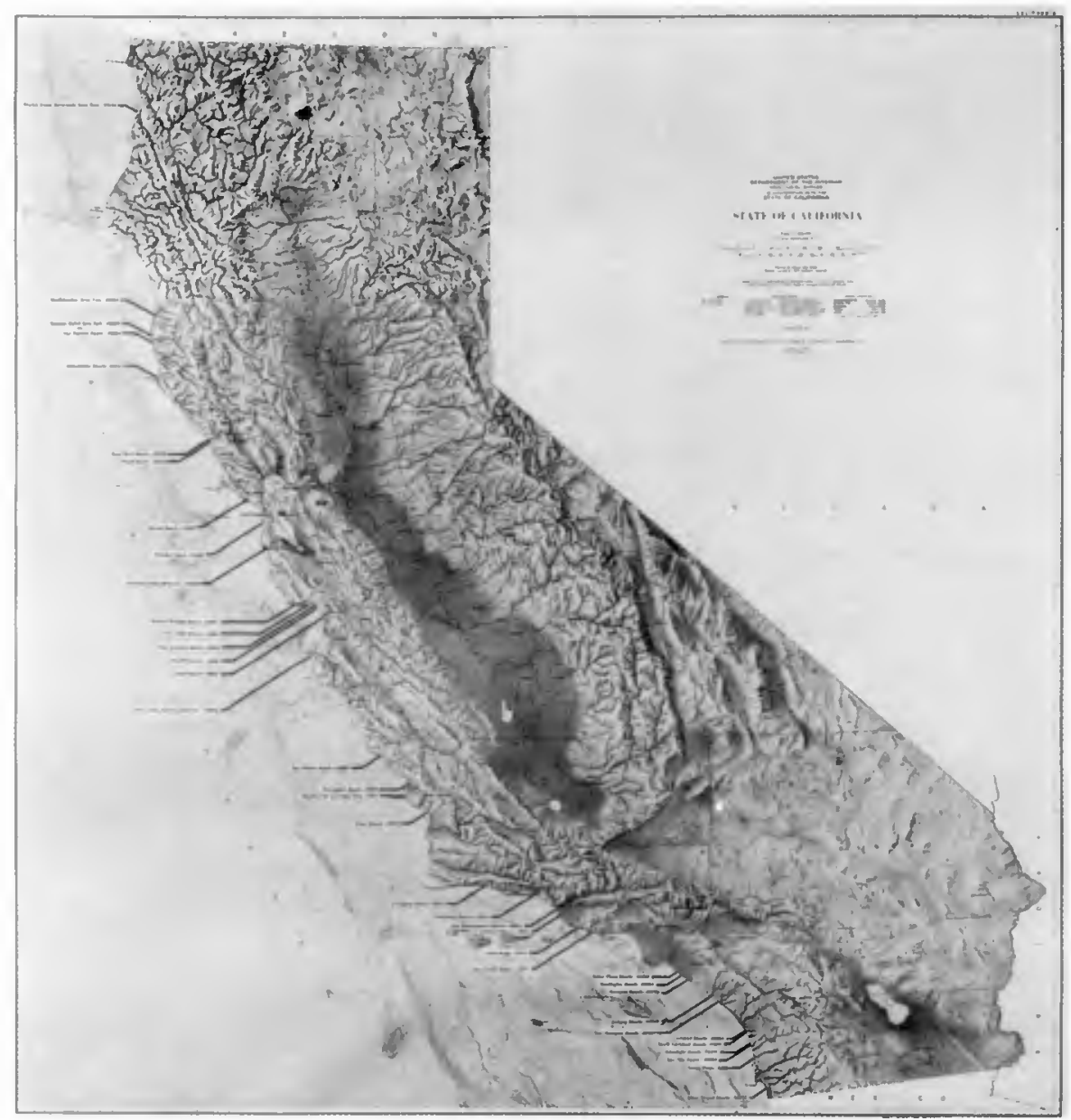

Fig. 1. Map of California showing the locations of Littoral Frvironment Observation Sites. 


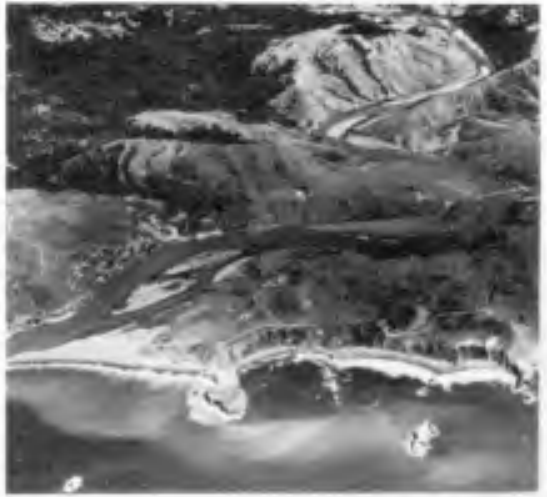

a. Goat Rock Stote Beoch,Sonomo Coost.

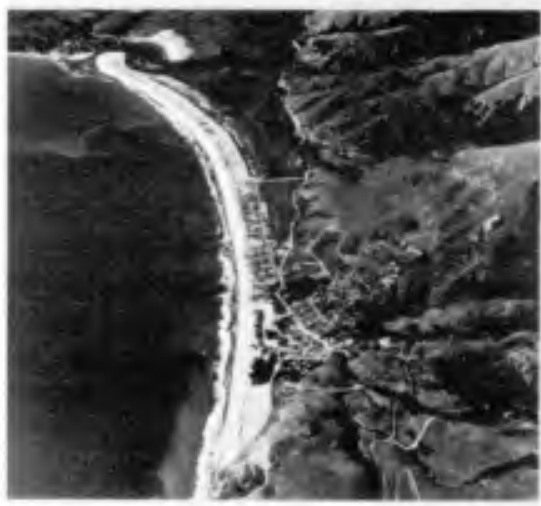

c. Stinson Stote Beoch.

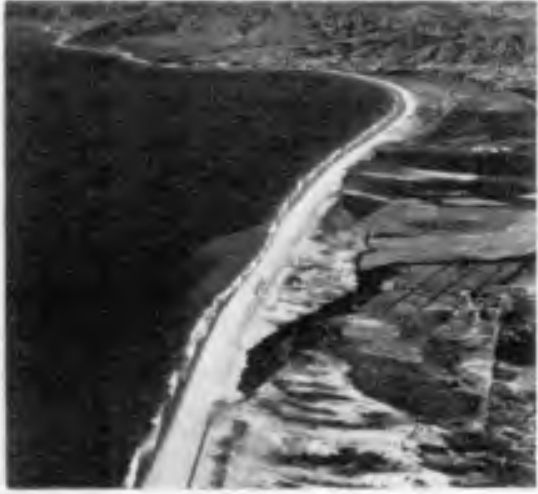

b. Son Buenoventuro Stole Beach ond MeGroth State Beoch.

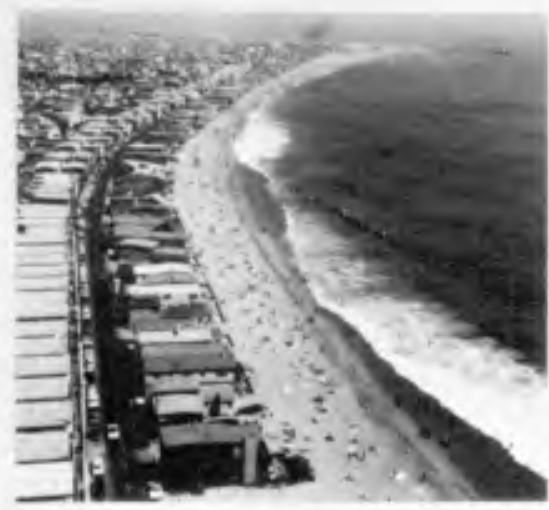

d. Newport Beoch, City of Newport Beoch.

Fig. 2. Aeriol photogrophs of typicol Colilornlo Littorol Environment Observotion sites. 
LITTORAL ENVIRONMENT OBSERVATIONS

Instructions for tilling out CERC form No 32

CeRC form No 32 has been desigred for processing by optical scanning equipment This equipment automatacally reads the observation forms and converts the recorded dats to punched cards which will then allow analys 15 of the data by computer methods it is therefore
recommended that numbe 2 black lead pencil be used to mark the forms when data positions are marked the mark should be made the ful1 length of the mark positions and should f111 at least twa-thirds of the space between the tap and botrom of the guide lines The parks should not extend more than $1 / 16$ beyond the ends of the gude 11 nes and 1 no case should they be extended beyond the marg in on the $r$ ght
shoug hand side of the form Marks beyond the margin will result 2 in errone ous reading of the data form. If

STATION 1 DEMTIFICATIUN

Bach site in the lit tarai Environment observation study hag been assigned a numercal code consisting of 5 digits The first two digits define the state or territory in which the site 15 located and the remaining 3 diglts define the partlcular beach or park w1than the in DATI

Indicate in the spaces provided the year month and day on which an observation is made

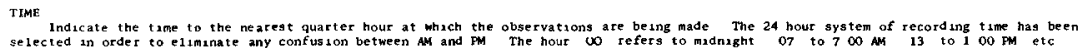
SURF OBSERVATIONS

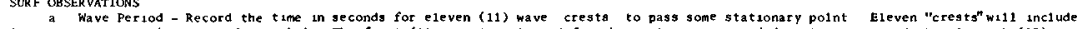
ten complete waves (crests and troughs) The first (1) crest selected for abservation is recorded as time zero and the eleventh (11) crest will be the stop or cut time Record this time in seconds in the spaces provided

or Wave Height - Thla observation 19 based solely on the jutgement of the observer Natural or manmade features on the shoreline or 1 the surf zone whose dimensions are known may axd in judging the height of a wave utherwise the observer s best estimate will he surf che have Direction - To indicate the direction of the approaching waves the observer must know the approximate orientation of the veach with respect to north The observer can then determine the direction from wh1ch the waves are approaching the beach

d Type of Breaking wave

Spilling - Spliling occurs when 1 he wave crests becomes unt table at the tap and the crest flows down the front face of the wave plung - producing an irregular foamy water surface (see figure 1 on teverse $s$ ide)

plunging - Plunging occurs when the wave crest curls over the front face of the mave and falls into the base of the wave Surg1ng - Surging occur $g$ when the wave crests remains unbroken while the bage of the front face of the wave advances up the
beach (see figure 3 on reverse 31 de)

WIND UBSER VATIONS

W Wind Velocity - A wind meter 25 provided to each observer and it as recommended that the instructions provided wath the meter
followed to obtain wind vel ocity measurements

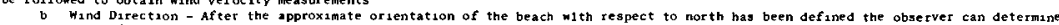
$b$ Wand Direction - After the approximate
the disection from which the wind is coming

BEACH OBSERVATIONS

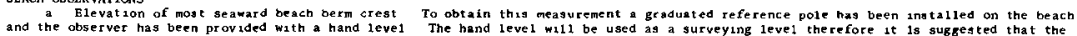
observer provide hamself pith a verith a hand level The hand level will be used as a surveying level the refore it 15 suggeat ted that the length say 4 or 5 feet After locating the position of the most seaward beach berm crest the observer stand ing on the berm crest and using his level will take a reading of the gradusted reference pole This resding minus the known length of the Ievel support sha11 be indicated on the form in the spaces prowided Space is 9190 provided on the form to indicate whether the elevation 15 pius or manua b Distance of most seaward beach berm crest from reference pole The observer will measure the distance from the anstalled c Angle of the foreshore siope For this measurement it 18 suggested that the observer have with him a clap board Lay the cilp

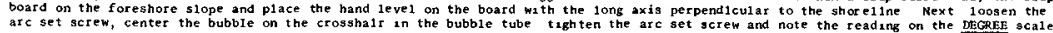

LITTORAL CURRENT OBSERYATIONS

3 Current Velocity For this measurement the observer has been provided wath dye The dye should be thrown into or just forward of

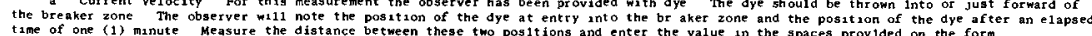
time of one (1) minute Measure the distance between these tho positions and enter the value in the spaces provided on the form
o current drect ion Having already estabished the approximate orsentation of the beach the observer can readily determane the
darection an which the dye or current is moving

TIDE LEVEL

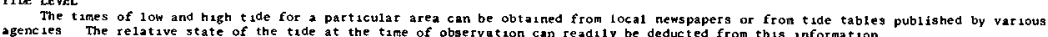

ARE RIP CURRERTS PRESENT?

Rap currents are defined as seaward movang channe 1 s of water whach return the water that has been piled up along the shore by incoming waves Rip currents are fed by feeder currents, water moving alang the shore (see figure at $r$ ight) Two currents yoin and extend out $1 \mathrm{n}$ what 19 known a lane neck where the water rushes through the breaker zone in a narrow ane Beyond the breakes zone the current spreads out in what is cal1ed if multaple currents exist record the distance between such rap currents

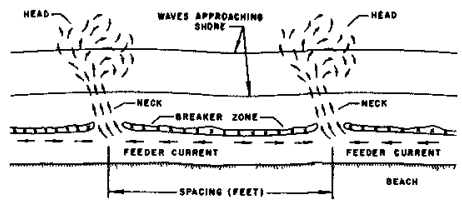

Fig. 3.a. Obverse side of Littoral Environment Observations instructions. 


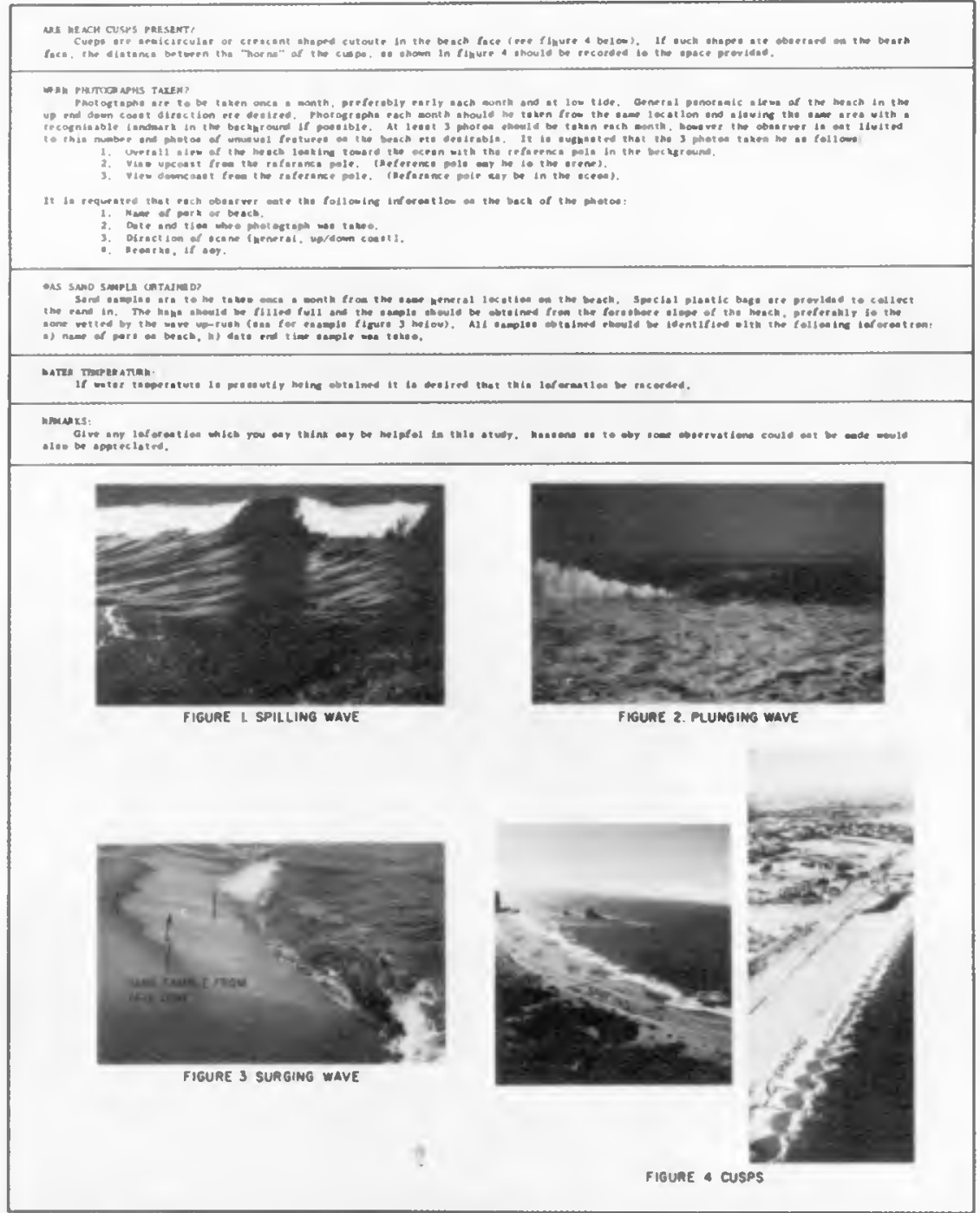

Fig. 3.b. Reverse side of Littoral Environment Observations instructions. 


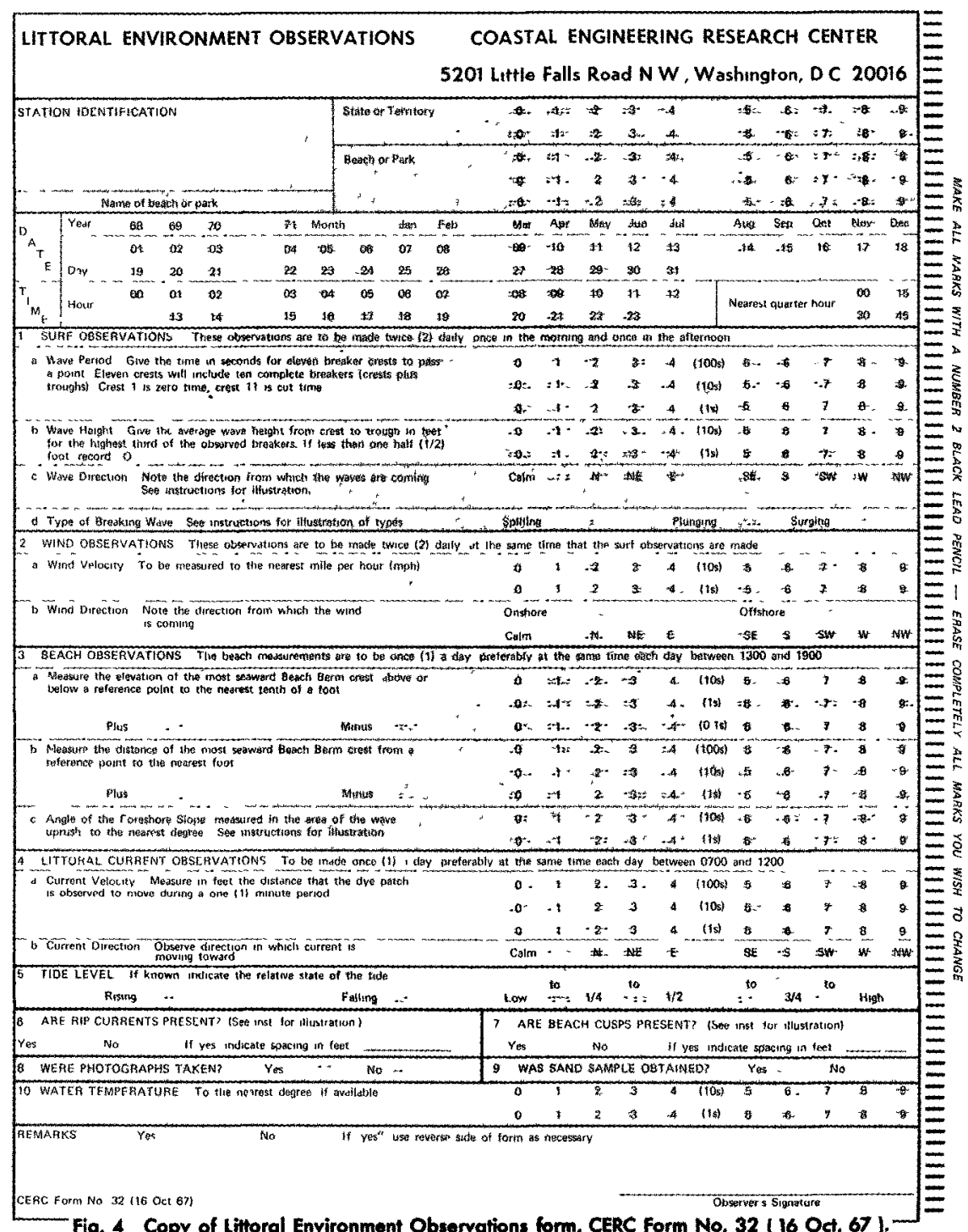




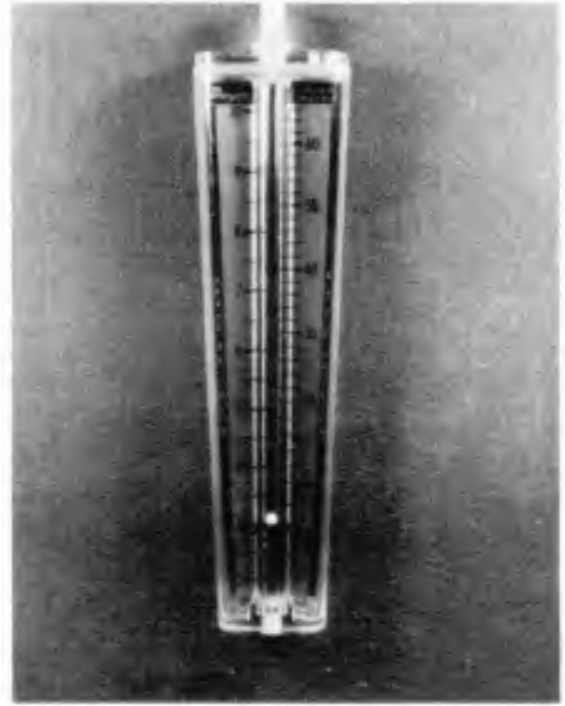

Fig. 5. Photograph of Dwyer Wind Moter used in measuring predominate wind velocities. 


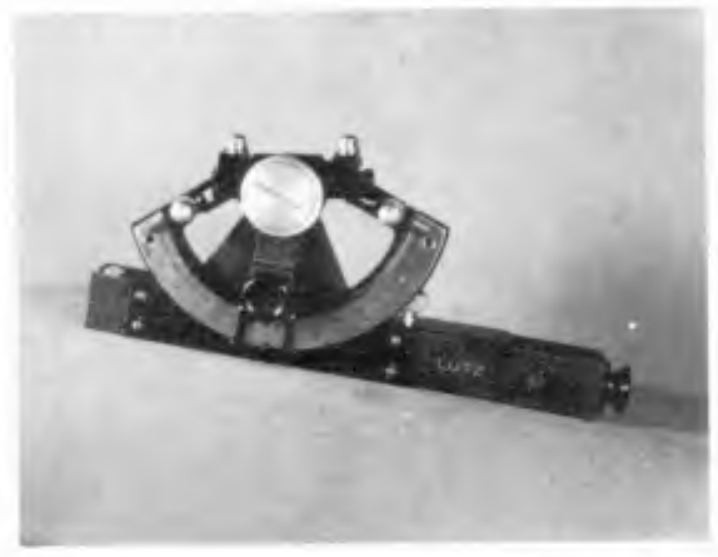

Fig. 6. Phatograph of Abney Tapagraphic Hand Level being used as an inclinameter ta measure the angle of the foreshare slope. 

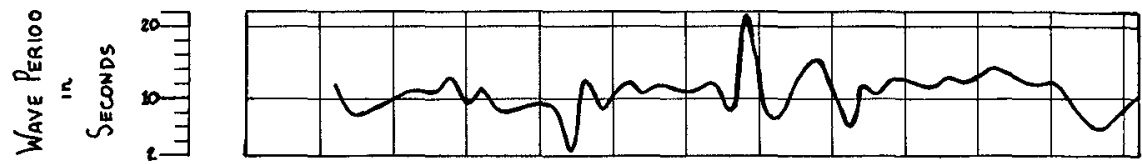

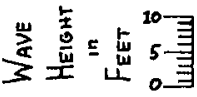

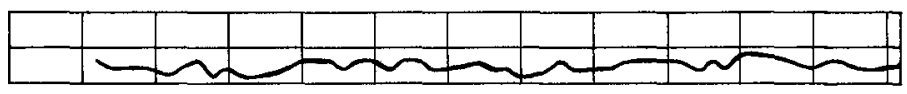

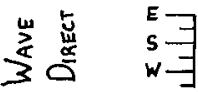

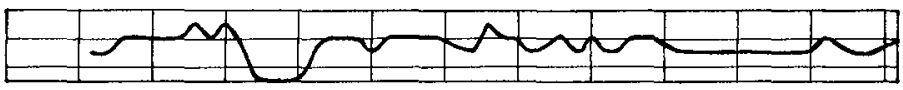

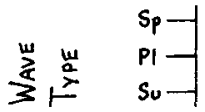

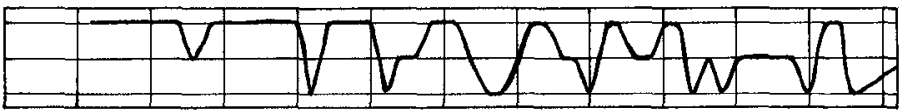

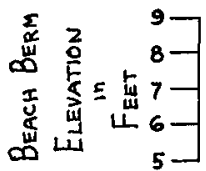

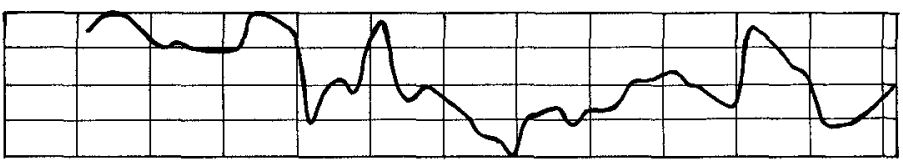

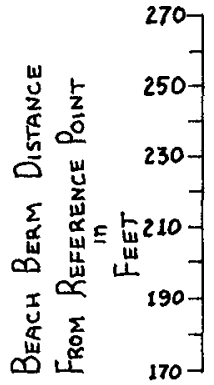

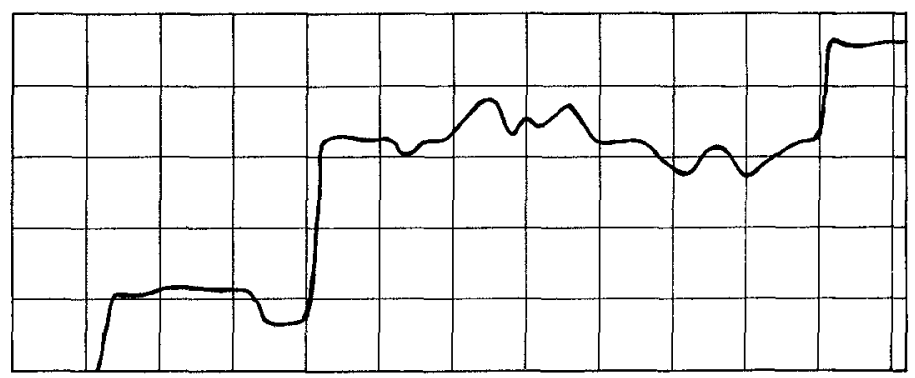

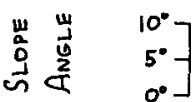

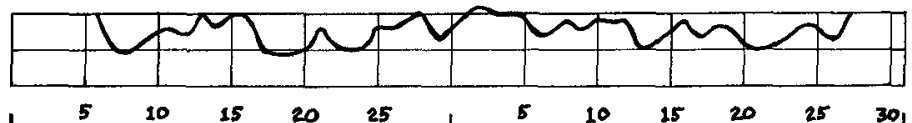

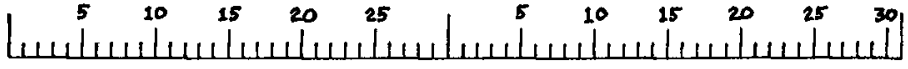
APRIL

MAY

Fig. 7 Graphical presentation of Surf and Beach Observations,

Seacliff State Beach, April - May, 1968 


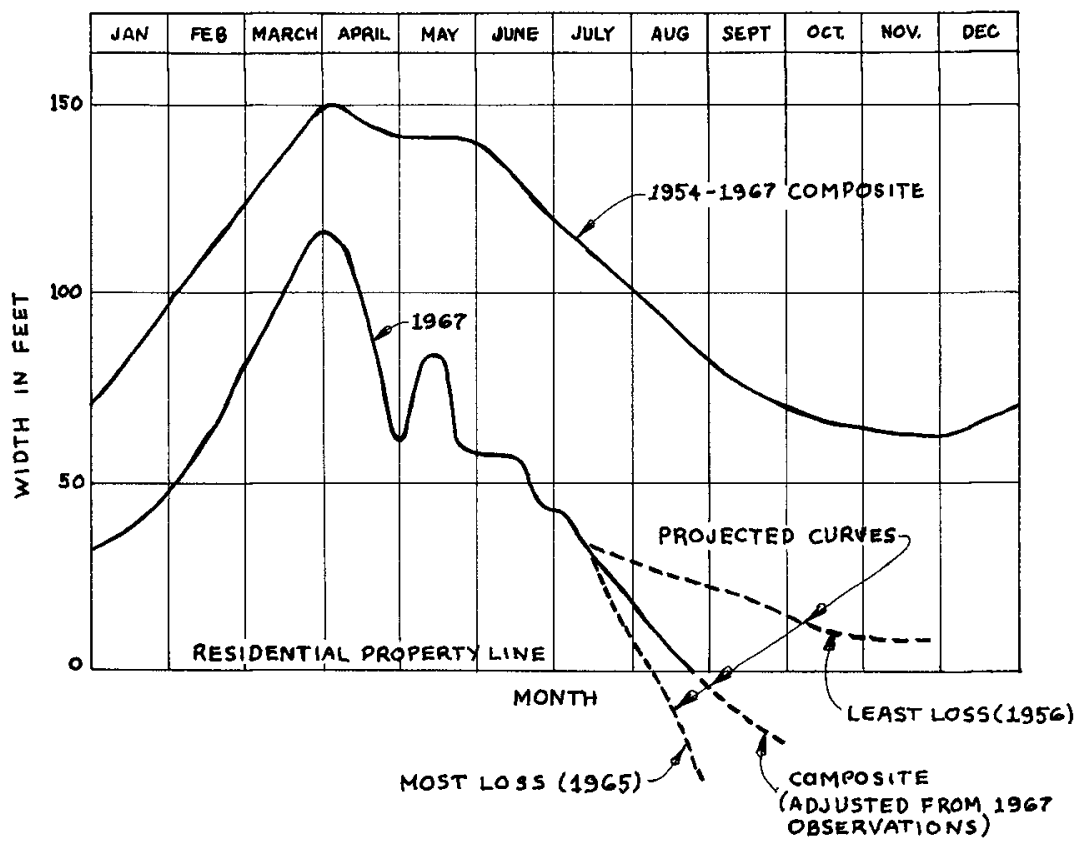

NOTE

I WLTTH FIGURE SHOWN IS WDTH OF LEVEL BEACH FROM SOUTHERLY LNE OF PRIVATE PROPERTY

LOCATION FROM 1954 TO 1964 is 36 th ST, FROM 1965 ON IS 41 ST ST

2.PLOTTED FROM DATA FISRNISHED BY CITY OF NEWPORT BEACH, PUBLIC WORKS DEPARTMENT

DATA OBSERVED BY MA ROBERT E REED, CHIEF LIFEGUARD

Fig 8. Graphical presentation of observed beach widths, Newport Beach. 


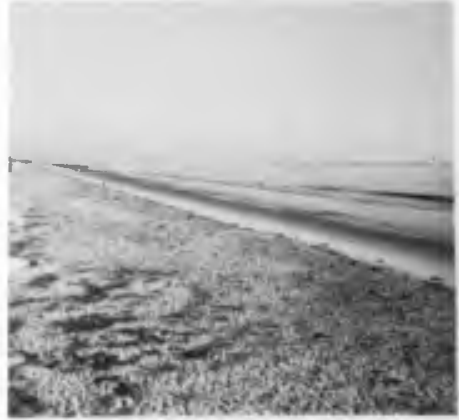

4 NOV. 1967
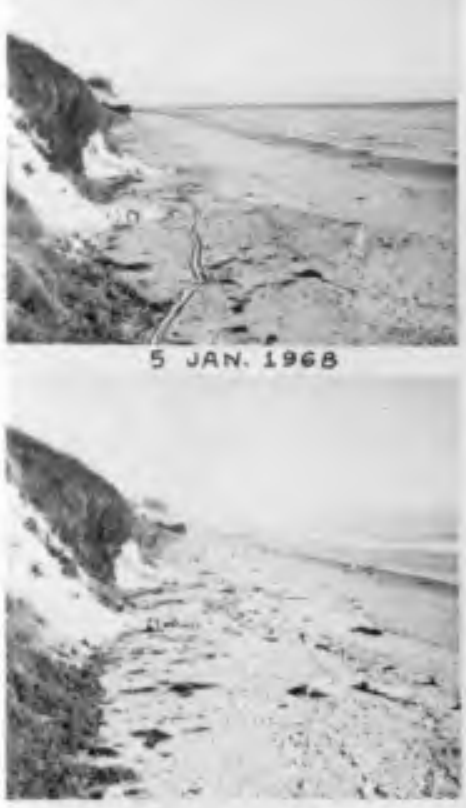

3 MAR. 1968

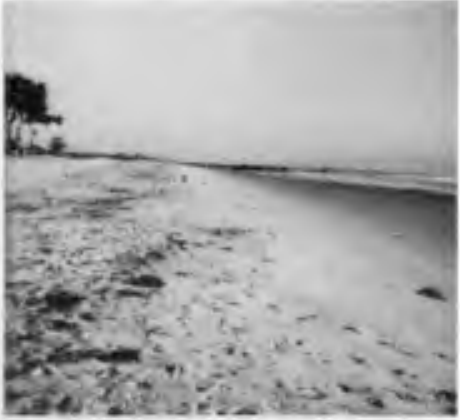

4 NOV. 1967

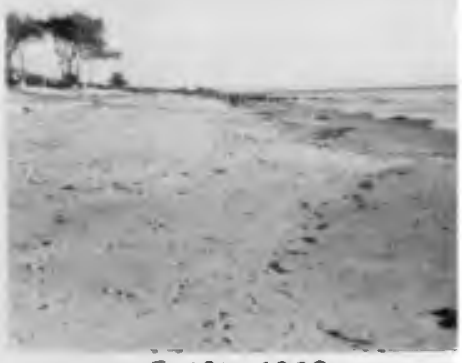

5 JAN. 1968

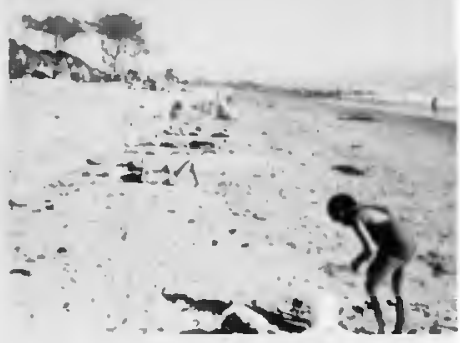

3 MAR. 1968

Fig. 9. Panoramic photographs of El Capitan State Beach, California taken during Nov. 1967, Jan. and March 1968. 


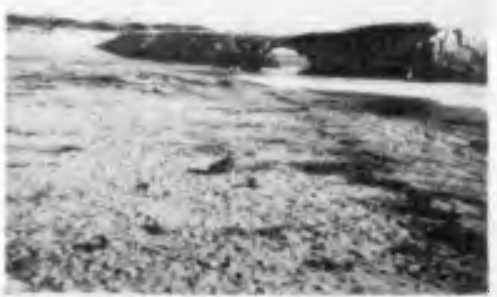

11 NOV. 1967

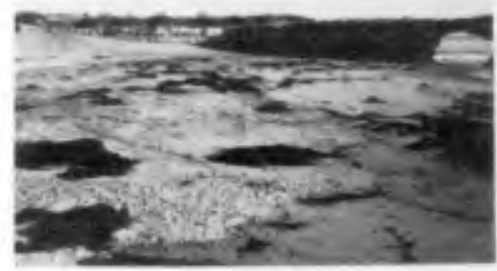

11 DEC. 1967

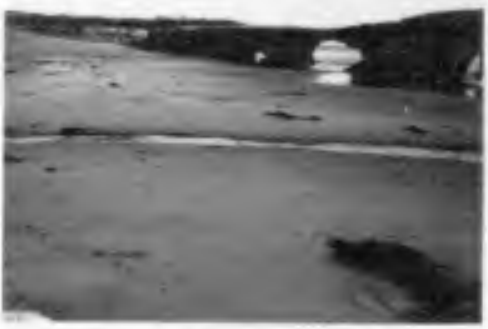

11 JAN. 1968

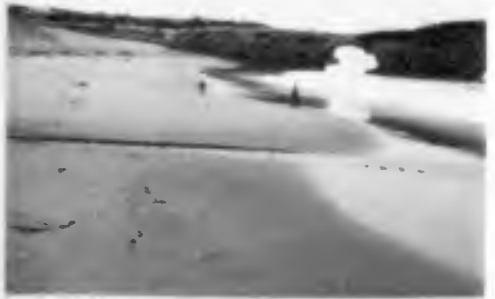

11 FEB. 1968

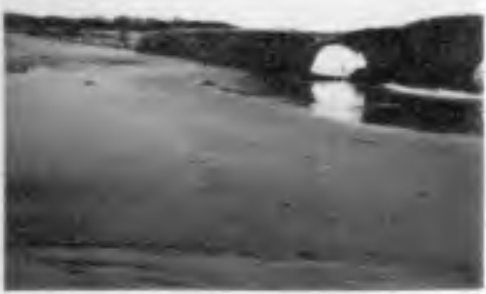

11 MAR. 1968

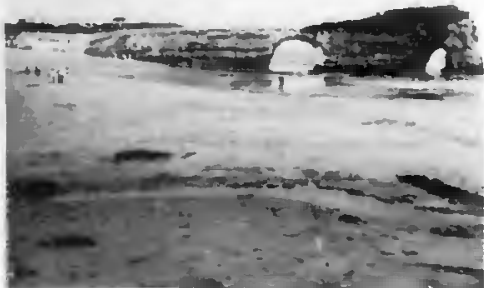

11 APR. 1968

Fig. 10. Panaramic phatographs of Notural Bridges State Beach, California taken during the period Nov. 1967 through April 1968. 